\title{
Vahşet Tiyatrosu ve Şiddetin Politiği: Edward Bond Örneği
}

\author{
The Theatre of Cruelty and the Politics of Violence: The Case of Edward Bond
}

\author{
Önder ÇAKIRTAŞ**
}

\begin{abstract}
$\ddot{O} \mathbf{z}$
Her dönem ve coğrafyada insanlığın maruz kaldığı önemli sorunlardan biri kişilerarası ve toplumlararası şiddettir. Şiddetin varlığı toplumların sosyokültürel yapısına bağlı olarak değişkenlik gösterse de, şiddet unsurları sözlü, yazılı, psikolojik ve fiziksel olabilir. Şiddetin yol açtığı tahripler, travmalar, kayıplar, psikozlar, depresif ve takıntılı davranışlar insanın bedeninde ve ruhunda çokça etkiler bıraksa da, şiddetin oluşumundaki etkenler de son derece önemlidir. Savaşlar, göçler, ırkçı ve aşağılayıcı söylemler, tacizler, tecavüzler, işkenceler, suçlar, kişilik bozuklukları, şizofren veya sapkın kimlikler vb. şiddetin kişisel veya toplumsal nedenlerindendir. Uzun yıllar madde bağımlısı olan, şiddetin maddi ve manevi yönleriyle mücadele eden ve on iki yıl boyunca çeşitli sağlık kurumlarında tedavi gören Antonin Artaud, şiddetin pratiğini barındıran vahşet tiyatrosunu tanıtırken, metin ve performans arasındaki ayırımı pratiğe dönüştürür ve sahnenin insan bedeninin her organını ayrıştırıcı güce sahip olan bir gerçeklik olduğunu iddia eder. İniltilerin, çığlıkların, bağrışların, acı(n)ma hissinin duyular aracılığıyla bütün organları çevreleyebileceğini; ses, 1şık, soluk ve dilin birer somut karakter olarak sahnede maddeleşmesi gerekliliğini savunur. Artaud merkezli bir yaklaşımla tiyatro, insan hal ve hareketlerinin ve ayrıca his ve ruhunun sahnede somutlaşmış halidir. Tiyatro, katarsisin seyircilerce izlenilen yerden yaşanılmasından öte sahnede yaşanmışlı̆̆ıdır. Artaud ile yakın dönemlerde yaşamış Edward Bond da çeşitli oyunlarında bu tiyatro kuramının izleklerini seyirciyle buluşturur ve vahşet tiyatrosunun unsurlarını kullanarak şiddetin insan yaşamının sıradan bir parçası haline geldiğini örnekler. Özellikle Saved (Kurtulmuş) (1965) adlı oyununda şiddetin insan yaşantısının politik bir yansıması olduğunu, var olmanın ideolojisi içinde şiddetin hüküm sürdüğünü, kişilerin hayatta kalmak için ilkel insandan modern insana bir metamorfoz sürecinden geçtiği halde şiddetin bir güç unsuru olarak ontolojik bir yapı olarak temellendirildiğini yansılar.
\end{abstract}

Anahtar sözcükler: Antonin Artaud, vahşet tiyatrosu, şiddet, Edward Bond, Saved.

\begin{abstract}
One of the important problems that humanity faces in every period and geography is interpersonal and intercommunal violence. Although the existence of violence varies depending on the socio-cultural structure of societies, elements of violence can be verbal, written, psychological and physical. Although violence-induced irritations, trauma, loss, psychosis, depressive and obsessive behaviours affect much in the human body, the factors that influence the formation of violence are also of great importance. Wars, migrations, racist-pejorative discourses, harassment, rape, tortures, crimes, personality disorders, schizophrenic or perverted identities, etc. are all personal or social causes of violence. Antonin Artaud, who had been exposed to substance abuse for many years struggled with material and spiritual aspects of violence and had been treated in various medical institutions for twelve years, introduces the Theatre of Cruelty, which contains the practice of violence. He suggests that the stage is a reality that has the power to set apart every organ of the human body; that moans, screams, painful and emotional feelings can surround all the organs through the senses; and that sound, light, breath, and tongue must be materialized on stage as concrete characters. Therefore, the theatre with the Artaudian approach is the embodiment of the human state and actions as well as the human feelings and the spirit on stage. The theatre is the platform where catharsis is experienced on stage rather than being by the audience. Edward Bond, living about the same period with Artaud, also
\end{abstract}

\footnotetext{
* Dr. Öğr.Üyesi, Bingöl Üniversitesi, Fen Edebiyat Fakültesi, İngiliz Dili ve Edebiyatı Bölümü, ocakirtas@bingol.edu.tr
} 
presents Artaud's theories of this theatre in his various plays and uses the elements of the Theatre of Cruelty to illustrate that violence has become an ordinary part of human life. Especially in Saved (1965), violence is a political reflection of human experience, and the presence of violence in the ideology of existence is reflected in the fact that violence is based on an ontological structure as a power element though people experience a primitive humanmodern human metamorphosis.

Keywords: Antonin Artaud, the theatre of cruelty, violence, Edward Bond, Saved.

\section{Giriş $^{1}$}

Şiddetin çalışıldığı alanlar çok çeşitlidir. Bilinçli ya da bilinçsiz bir insan davranışı olan şiddet, ruh biliminden sinir bilimlerine, doğa bilimlerinden insan bilimlerine, fizik bilimlerinden anatomiye dek birçok alanın çalışma konusu olmuştur. Edebiyat da bu çalışma alanlarından biridir. Dünya edebiyatlarında olduğu gibi İngiliz edebiyatında da şiddetin yansıyışı çeşitlidir. Her ne kadar İngiliz edebiyatında erken dönemlerde 'şiddet/vahşet romanı, tiyatrosu, şiiri' gibi başlıklar altında bir kategorileştirme/isimlendirme olmasa da şiddetin varlığı örnekleriyle aşikârdır. Sözgelimi, İngiliz edebiyatının var olan en eski epiği kabul edilen Beowulf'da Beowulf'un Grendel ile şiddet içeren çekişmeleri ve nihayetinde Beowulf'un bu canavarı katledişi; İngiliz edebiyatının örneklediği Sofokles'in Kral Oedipus oyununda fiziksel, psikolojik ve sosyal şiddet; ileriki dönemlerde on altıncı yüzyılda Shakespeare'in neredeyse tüm tragedyalarında, örneğin, Hamlet'te Hamlet'in babasının intikamı için Kral Claudious ile savaşımları ve ölümler, Hamlet'in ve Ofelya'nın psikolojik şiddet içeren devinimleri, Othello'da Othello'nun Desdemona'yı kıskançlı̆ğıdan kaynaklanan şiddet unsurları ve ölümler, Macbeth'de Leydi Macbeth ve Macbeth'in Makyavelist hırslarından doğan fiziksel şiddet, psikolojik travma ve ölümler vb. on sekizinci yüzyılda Mary Shelley'nin gotik romanı Frankenstein'da var olan fiziksel şiddet olgusu ve yansımaları; on dokuzuncu yüzyılda Charles Dickens'ın Büyük Umutlar'ında Pip'in yaşadığı fiziksel ve psikolojik şiddet; yirminci yüzyılda Charlotte Brontë’nin Jane Eyre romanında Jane'in yaşadığı fiziksel, sosyo-ekonomik, psikolojik ve cinsel şiddet; Emily Brontë'nin Uğultulu Tepeler romanında Heathcliff ve Catherine'in yaşadığı sosyo-ekonomik, fiziksel ve psikolojik şiddet; yirminci yüzyılın ikinci yarısında Samuel Beckett' in Oyun Sonu oyununda Hamm ve Clov'un yaşadığı psikolojik, sözlü ve fiziksel şiddet bu kavramın varlığını ispat eder. Örnekleri katlamak mümkün, çünkü neredeyse her edebi yapıtta bu olguyla karşılaşmak kuvvetle muhtemeldir.

Yukarıdaki örneklerden çıkarılacağı üzere şiddet/vahşet edebi metinlerin tematik bir parçasıdır. Bu sebeple bu çalışma insan yaşamının sürekli bir parçası haline gelmiş/getirilmiş şiddet/vahşet olgusunu açıklamayı, şiddetin bireyin varlığı üzerindeki etkilerini irdelemeyi ve edebiyat türlerinden tiyatroda nasıl yansılandığını aktarmayı amaçlar. Bu bağlamda bu çalışmanın özü Antonin Artaud'nun insan eylemlerinin doğal olarak şiddeti doğurduğu gerçeğiyle literatüre tanıttığı vahşet tiyatrosunu İngiliz tiyatrosunun postmodern öncülerinden Edward Bond'un bir oyunuyla örnekleyerek açıklamaktır. Çalışmanın ilk bölümü şiddet kavramının etimolojik ya da sözlük bilimsel tanımlamasını ve bu kavramın çeşitli türlerini kapsar. İkinci bölümde şiddetin sahnede eyleme dönüşmesi kapsamında Artaud'nun vahşet tiyatrosu irdelenir. Üçüncü bölümde Edward Bond'un Saved oyunu ile ilişkili olarak hem şiddet olgusu hem de Artaud düşüncesinde vahşet ele alınır. Ve çalışma elde edilen bulgularla sonuçlandırılır.

\section{Şiddet Nedir?}

Türk Dil Kurumu Sözlüğ̈̈̈’nde şiddet “Bir hareketin, bir gücün derecesi, yeğinlik, sertlik” veya "Duygu ve davranışta aşırılık" (Şiddet, t.y.) olarak tanımlanır. Aynı sözlükte bu kavramın Türkçeye Arapçadan geçtiği belirtilir. Arapçada ise "peklik", "sertlik" ve "sıkılık" anlamlarını taşır (Dursun, 2011, s. 3). İngilizcedeki karşılığı violence olan şiddet kavramının Türkçedeki tanımlamadan farklı olduğu görülür. Oxford Sözlüğ̈̈'nde "Birini veya bir şeyi incitmek, zarar vermek ya da öldürmek niyetiyle uygulanan fiziksel güç davranışı" veya "Bir duygunun ya da yıkıcı doğal bir varlığın gücü” (Violence, t.y.) şeklinde tanımlanır ve Latincedeki violentia sözcügünden türediği aktarılır. Amerikan Psikoloji Derneği Psikoloji Sözlüğü ise bu kavramı "Fiziksel güç kullanarak insanları veya mülkleri yaralama veya

\footnotetext{
${ }^{1}$ Bu çalışmada İngilizce kaynaklardan yapılmış tüm alıntılar yazar tarafından Türkçeye çevrilmiştir.
} 
onlara zarar verme niyeti ile yapılan düşmanlık ve öfke ifadesi” (VandenBos, 2015, s. 1139) olarak tanımlar ve bu kavramı "patolojik saldırganlık" (pathological aggression) terimi ile bağdaştırır. Bu kavram ise aynı sözlükte şöyle tanımlar:

Şiddet içeren, açıkça bireylere veya mülkiyete yöneltilen saldırganlık; yıkıcı ya da can sıkıcı bir davranımın varlığını uzun süre gösteren bir yapı parçası; ya da gerçek veya algılanan provokasyona karşı gösterilen ani, paroksismal tepki. Bu durum psikiyatrik bir bozukluğun göstergesi olabilir (örn. Psikoz, travma sonrası stres bozukluğu, antisosyal kişilik bozukluğu, bazı uyarı-kontrol bozuklukları); ya da nörolojik hastalık veya yaralanma veyahut madde bağımlılığının göstergesi (örn. Alkol) ve bazı cinsel davranışların göstergesi (ör. Cinsel sadizm) olabilir. (s. 769)

Dünya Sağlık Örgütü'nün şiddet kavramını tanımlanmasında ise iki durum dikkat çekicidir. Birincisi, "Yaralanma, ölüm, psikolojik zarar, kötü gelişim veya yoksunluk ile sonuçlanan ya da sonuçlanması yüksek ihtimal olan bir durumun, fiziksel güç ya da kuvvetçe uygulanması" (Krug, 2002, s. 5) görüşüdür. İkincisi ise bu eylemin "bir tehdit ya da gerçeklik olarak birey(ler) tarafından kendine, başka bir kişiye, bir gruba ya da topluluğa karşı kasıtlı kullanılışını" (s. 5) içermesidir. Dolayısıyla şiddet bir gücü gerektirir ve eylemsel durumlar öncelikle bireysel olmak üzere çok çeşitli sonuçlar doğurur. John Docker şiddetin anormallikten ziyade, insan etkinliklerinin özünde olan bir özellik olduğunu belirtir ve insanlık tarihinin şiddet tarihinin temeli olduğu düşüncesini "savaş ve soykırım; fetih ve sömürgeleştirme ve Tanrı tarafından onaylanmış imparatorlukların yaratılışı; çok tanrılılık ve monoteizm çekişmeleri; demokrasi ve imparatorlukların ölümcül kombinasyonu; devrim, katliam, işkence, mutilasyon ve zulüm" (2008, s. 2) gibi kavramlarla bütünleştirir. Bu haliyle Docker bireysel şiddetten daha çok toplumsal ve uluslararası şiddet üzerine odaklanır.

Şiddetin insan etkinliklerinin özünü oluşturduğu düşüncesi bir eylemsel durumun olduğunu ifade eder. Dolayısıyla eylemin yapılabilirliği sahip olunan fiziksel, psikolojik, toplumsal, ekonomik ve politik gücün varlığıyla orantılıdır. Bu durum şiddetin eyleme geçirilmesi noktasında var olan yönetimsel rejimleri de kapsar. Tiranlık, faşizm, diktatörlük, androkrasi gibi yönetimsel ideolojiler gücün şiddete dönüştürülerek kullanımını zorunlu kılar. Bu şekliyle bu durum Trudy Govier'in aktardığı şiddet tanımlarıyla örtüşür. Çünkü Govier "Savaşlar, direniş, devrim ve terörizm bağlamında ateş etme ve bombalama gibi araçlarla kişileri ve mülkleri yaralama, öldürme, onlara zarar verme ve onları yok etme" (2008, s. 62-63) gibi konuları kapsayan fiziksel şiddetin eylemselliğinin görünürlüğüne vurgu yapar. Ancak varlığ 1 gizil olarak sürdürülen yapısal şiddet (structural violence) ve psikolojik şiddet (psychological violence) kavramlarının toplumda şiddetsizlik (nonviolence) olarak benimsendiğini iddia eder. Şiddetsizliğin de protesto, ölüm orucu, dilekçe verme, broşür dağıtma, kitlesel gösteriler, grevler ve yapılacak ödemelerin kesintisi, toplumsal eylemler gibi bask1 ve güç üsluplarıyla sağlanabildiğini belirtir.

Şiddetin varlığı, türü ve yapısı bireysel ve toplumsal ilişkilerde ortaya çıkar. Burada asıl olan ile potansiyel olan arasındaki durum önemlidir. Johan Galtung'a göre "Şiddet, potansiyel olan ile gerçek olan arasındaki mesafeyi arttıran ve bu mesafenin azalmasını engelleyen şeydir" (1969, s. 168). Şiddetin ortaya çıkış nedenleri de Galtung'un bu tanımı etrafında yoğunlaşır. Bu nedenleri Stephen C. Morris beş başlık altında siralar:

1. Bireysel Faktörler: Biyolojik ve demografik faktörler, istismar ve eğitim geçmişi, uyuşturucu maddelerin kötüye kullanımı

2. İlişkiler: Aile ve yakınlar, şiddete yakınlığı ve kabul edilebilirliği

3. Toplum: Şiddet kurumları, mahalle, geçici topluluklar, sosyal doku ve kültürel destek kaybı, toplumsal tecrit

4. Toplumsal Faktörler: Şiddetin kültürel olarak kabul edilmesi, sosyal güç uyumsuzluğu, kültürel sınırlılıkların kaybı

5. Karmaş1k etkileşimler: Savaş, mezhepsel şiddet, toplumsal çöküş, açlik, afet (2007, sayfa belirtilmemiş)

Morris'in bu sınıflandırmasından da anlaşılacağı üzere şiddetin yapısı, varlığ1 ve türü ontolojik oluşuna ve bireyler, toplum ve doğa ile ilgili olaylara göre biçimlenir. Dünya Sağlık Örgütü’nün Şiddet ve 
Să̆llk Üzerine Dünya Raporu'nda ise şiddet üç ana alt sınıfta incelenir: "1- Birey tarafindan kendine yöneltilen şiddet, 2-Bireylerarası şiddet 3- Toplu şiddet" (Krug, 2002, s. 6) . Aynı raporda şiddet eylemleri şu şekilde sıralanır: "1- Fiziksel, 2- Cinsel, 3-Psikolojik, 4- Duygusal" (s. 6). Bu durumda, şiddetin birçok farklı çeşidi vardır; cinsel şiddet, psikolojik şiddet, aile içi şiddet, çocuk şiddeti, cinsiyet temelli şiddet, işyeri şiddeti (mobbing), medya şiddeti, politik şiddet, dinsel ve mezhepsel şiddet vb. bunlardan birkaçıdır Ancak her birinin ortaya çıkış nedeni ve sonuçları yukarıda aktarıldığı gibi değişken olabilmektedir. Nedenler ve sonuçlar her ne kadar farklı olsa da şiddetin her türünün zemini güç kullanımına dayanır. Dolayısıyla güç olgusu, bir diğer ifadeyle kasıtlı güç kullanımı, şiddetin ortaya çıkışına yol açar.

\section{Edebiyatta Şiddet ve Artaud'nun Vahşet Tiyatrosu}

Şiddet edebiyatta çoğunlukla işlenen bir konudur çünkü şiddet bireyin ve toplumun yaşamsal süreçlerinde olası bir hakikati barındırır. Yazarların var olan durumları aktardığı bir platform olan metinler, kişilerarası ve toplumlararası şiddetin de bir aktarıcısı olur. Şiddetin edebiyattaki yansımaları üzerine çokça araştırma yapılmıştır. İncelenen çalışmalarda, şiddet ve vahşet dünya üzerinde varlık sürdüren neredeyse her coğrafyada edebiyatların konuları olmuştur. Örneğin Amerikan edebiyatı üzerine çalışmalarda bulunan David Brion Davis şiddetin Amerikan kıtasının keşif yılı olan 1492'den beri Amerikan edebiyatının ana teması olduğunu belirtir (1966, s. 29). Kate Lawson ve Lynn Shakinovsky on dokuzuncu yüzyıl edebiyatındaki aile içi şiddet üzerine yazdıkları araştırmalarında, Tolstoy'un Savaş ve Barış epik romanına gönderme yaparak okuyuculara roman karakterlerinden Dolohov'un mizacına dönük bazı durumları aktarırken onun askerlerinden ikisinin sarsıcı diyaloglarında Polonya'da Yahudilerin öldürülmesine dair konuşmalarını verirler (2002, s. 1). Bu konuşmalarda Yahudi aleyhtarı bir yönelimle ortaya çıkan şiddet unsurlarına göndermede bulunma oldukça sıradan görülebilir ve bu durum okur tarafindan şaşırtıcı bulunabilir. Ayrıca, bu konuşmaların tonu okurda, Yahudileri suçlar tarzda bir algı oluşturmasına karşılık durumun sıradanlığını da yansıtır. Türk romanında aile içi şiddet üzerine incelemelerde bulunan Ayfer Yılmaz şiddeti psikolojik ve fiziksel olarak iki sınıfta irdeler (2005, s. 13841). Peyami Safa'nın Mahşer, Reşat Nuri Güntekin'in Acımak, Halikarnas Balıkçısı'nın Aganta Burina Burinata, Orhan Kemal'in Bir Filiz Vardl, Reşat Nuri Güntekin'in Yaprak Dökümü eserlerinde ve burada belirtilmemiş daha birçok eserde psikolojik şiddeti aktarır. Ayrıca Ahmet Mithat Efendi'nin Çengi, Namık Kemal'in Intibah, Halit Ziya Uşaklıgil'in Mai ve Siyah, Halide Edip Adıvar'ın Mev'ut Hüküm, Melih Cevdet Anday'ın Aylaklar eserinde ve burada belirtilmemiş daha birçok eserde fiziksel şiddetin varlığını ifade eder. On dokuzuncu yüzyıl İngiliz edebiyatında da dönemin yazarları toplumsal cinsiyet rolleri bağlamında birçok cinsiyetçi şiddet öğeleri içeren yapıtlar üretmiştir. Örneğin, Bernard Shaw Bayan Warren'ın Mesleği'nde 'toplumsal şiddetin' varlığından söz eder ve kadına dair her türlü fiziksel, duygusal ve psikolojik şiddetin varlığının Viktoryen klişesinin öğretisi olan 'kadın gibi kadın' söylemiyle şekillendiğini aktarmaya çalışır. Benzer şekilde, Arthur Miller Cadı Kazanı oyununda kadının toplumca şeytanileştirilmesini işler ve 1rkçı, yermeli şiddetin toplumsal bir 'sıradanlığa' dönüşümünü gerçekçi bir üslupla sahneler.

Geleneksel Türk tiyatrosu üzerine araştırmaları olan Aslıhan Ünlü yukarıdakilerden oldukça farklı bir yaklaşım sergiler (2007, s. 28). Geleneksel tiyatroda "oyun ve şiddetin iç içe" (s. 28) olduğundan söz eden Ünlü, şiddetin geleneksel tiyatrodaki varlı̆̆ını bir olumlama ile ifade eder: "Şiddet pek çok toplumda kutsal olanın ve törenlerin ayrılmaz bir parçasıdır. Günlük yaşamdaki şiddetten, yani zararlı, yıkıcı şiddetten kaçmak için bunun oyunlaştırıldığı, böylece sağaltıcı, yararlı şiddete geçildiği de görülmektedir". Ünlü bu durumu insan yaşamı ve doğa ile ilişkilendirir ve toplumsal ve çevresel koşulların etkisiyle korku ve şiddetin oyunlarda bolca sergilendiğini iddia eder (s. 29). Bunların bir sonucu olarak "Bireyin toplumsallaşmasında bir sınav olan erginlenme törenleri de korku ve şiddetin bileşimidir ve bireyi bunlara karşı aş1lı hale getirirken, topluluğun şiddetinin dışa vurulması, savuşturulması işlevini de yüklenir" (s. 29) der. Bu bağlamda şiddet oyunlaştırılırken aslında Artaud düşüncesinin bir yansımasını verir. Şiddetin sahnedeki varlığı her ne kadar bir 'oyun' ile temsil ediliyorsa da, aktarılmak istenen şey özfarkındalık yaratmaktır. Nitekim Artaud da geleneksel tiyatro ile vahşet tiyatrosu arasında bir bağ kurar. $\mathrm{Bu}$ bağ vahşet tiyatrosunun izlerinin geleneksel Bali ritüellerinden esinlenmesiyle de alakalıdır. Ancak Artaud'nun yaklaşımı Ünlü'nün aktardıklarından oldukça farklıdır. 
Vahşet tiyatrosu, avant-garde oyun yazarı, aktör ve kuramcı Antonin Artaud'nun Tiyatro ve İkizi adlı eserinde ortaya koyduğu teatral bir türdür. Sürrealist akımın temsilcilerinden olan ve çağdaşlarından farklı olarak kendi tiyatro kuramlarını geliştirmeye çalışan Artaud, vahşet tiyatrosunu tanıtırken geleneksel Batı tiyatrosundan bir kopuşu beraberinde getirir ve bu tiyatro aracılığıyla aktör ve aktrislerin yaratılan karakterlerle izleyicilerin duyularına saldırmasını amaçlar. Ayrıca kişilerin bilinçaltında yatan ifade edilmemiş duygularının hissedilmesine olanak tanınmasını güder. Burada sözü edilen Batıdan kopuş bir nevi tiyatronun ontolojik veya antropolojik varlığına dönüştür, çünkü Artaud'ya göre "tiyatro gösterisi, bir ayin niteliği taşımalı ve tiyatro yeniden ilkel büyü törenlerindeki etki gücüne kavuşturulmalıdır. Onun düşlediği tiyatro, antikçağ, ortaçağ, Uzakdoğu tiyatrolarından, ilkel büyü törenlerinden esinlenen metafiziksel bir tiyatrodur" (Gülmez, 1993, s. 8). Bu haliyle antik Misır, Roma ve Yunan tragedyalarının büyüsel ve mitsel yönüyle de ilgilenir. Çünkü Artaud'nun "Vahşet tiyatrosu vasitasıyla izleyicide bir şiddet eylemselliği başlatmak ve ardından onu saf dıșı bırakmak için yaptığı planın bir ruhu salıveren eski psikomedikal uygulamalar veya epileptik veya histerik hastalara sahip olduğuna inanılan tanrı ile çokça ortak noktası vardır” (Bermel, 2001, s. 31). Bu öz dönüşüm Artaud'nun benimsediği tiyatro anlayışına en uygun olandır. Bu uygunluk şüphesiz "Seyircileri irkiltme, yeni bir duyarlılığa yöneltme ilkesine dayalı" (s. 8) vahşet tiyatrosunun çarpıcı bir katharsisini barındırır.

Artaud, vahşet tiyatrosunun anlaşılmasını kolaylaştırmak adına "tiyatro" ve "vahşet" kavramlarının sözlük anlamlarından farklı tanımlamalarına değinir. Ancak buna değinmeden önce nasıl bir tiyatro ve tiyatro anlayışı olması gerektiğinin altını çizer. Artaud'ya göre "şiddetli doyum isteği" $(1993$, s. 75) sadece ve sadece "sinirlerimizi ve yüreğimizi uyandıracak bir tiyatro" (s. 75) ile mümkündür. Bundan dolay1 tiyatro "dolaysız ve şiddetli eylem alışkanlığına" (s. 75) sahip olmalıdır. Bu sayede tiyatro acılarımızı adeta bir makineden süzen ve bunları bize aktaramayan sinemadan, müzikhollerden ya da sirklerden kendini farklılaştırabilir; yani Artaud "imgelerin ateşli manyetikliğini içimize üfleyen ve sonuçta, unutulmayacak bir ruh tedavisini andırırcasına etkisini üzerimizde gösteren ciddi bir tiyatro düşüncesini”" (s. 75) benimser. İşte böylesi bir tiyatrodur vahşet tiyatrosu. Nasıl ki Augosto Boal tüm insan devinimlerinin zorunlu olarak politik olduğunu iddia ediyorsa, Artaud da "Etkinlik gösteren her şey vahşettir" (s. 75) der. Dolayısıyla Artaud tiyatrosu da vahşetin her anı kişileri acıtacak, azarlayacak, hor görecek, huzursuz edecek, kıvrandıracak veya onlara acı çektirecek bir tondadır. İzleyicinin aktifleştirildiği bu tiyatro anlayışında, sinirler ve kalp ortak bir uyandırma mekanizmasıdır. Artaud'nun en net söylemiyle açıkladığ 1 gibidir:

Vahşet tiyatrosu, seyircilerin önce duyu organlarıyla düşündüğünü ve alışılmış ruhbilimsel tiyatroda olduğu gibi, önce sağduyularına seslenmenin saçma olduğu düşüncesinden yola çıkarak, bir kitle gösterisi olacaktır. Büyük kalabalıkların, heyecan içinde, gerilip birbirine gireceği ve yerinde duramayıp çırpınacağ 1 bu tiyatroda, şimdi pek ender olarak görülen, halkın sokaklara döküldüğü bayramların, kalabalıkların şiirinden bir parça bulunsun isteriz (s. 75-76).

Dolayısıyla Artaud düşüncesinde sahne tam bir hareket alanıdır. Karakterler de bu bakımdan beden ve dilin mutlak etkileşimi içinde duyuların eylemselliğini teşvik edici konumdadır. Beden, dil ve beden dili seyircinin eylemsizliğini harekete geçirmekle meşgul olmalıdır. Bu durumda eylemsiz konumda olacak ne bir oyuncu ne de izleyici/okur vardır. Ros Murray bunu Artaud'nun "Bedensel varlık, aciliyet ve beden dili ile ilgili 1srarı, tiyatronun en azından ilk başta mükemmel bir araç gibi göründüğü anlamı taşıdığı" (2014, s. 58) görüşüne dayandırır. Çünkü seyircinin anlamlandırması gerekenler ancak sahnede sergilenebilen beden ve konuşma diliyle özünü ortaya koyar. Jacques Derrida ve Paula Thevenin'in The Secret Art of Antonin Artaud (Antonin Artaud'nun Gizli Sanatı) adlı çalışmalarında Thevenin'in Artaud'nun resim sanatına dair ilgisini aktarırken Artaud için semiyotik vurguların önemini ifade edişin arkasında "Söylemek zorunda olduğunuz şey, bizi kuşatan formlarla söylenebilir. Bir şeyler söylediğimizde, o şeyler söylediklerimizdir" (1998, s. 4) düşüncesinin olduğunu ima eder. Bu söylem vahşet tiyatrosunun eylemselliğinin anlamlandırılmasına dönük dil kullanımını ve diyalogları içerir. Buradaki dil sesin ta kendisidir. Artaud "Bu nedenle, seyircinin duyarlılığını her yönüyle işlemek amacıyla, sahneyi ve salonu birbirleriyle iletişimi olanaksız iki kopuk dünya kılma yerine, görsel ve sessel göz alıcılığını seyircilerin tümüne ulaştıracak döner bir gösteri” (1993, s. 76) alanı olarak anlamlandırır. 
Dil konuştukça sesler büyür ve insan ruhunun diplerindeki çı̆̆lıklar sahnenin uzamına ve zamanın ruhuna dokunur. Dolayısıyla ses dili, dil sesi yaratır:

Sözcükler ruha az şey söyler; enginlik ve nesneler konuşur; sözcüklerle yaratılmış olsalar bile, yeni imgeler konuşur. Ama zaman zaman, sessizlik ve devinimsizlikle donatılmış yeterli oranda uzamlar düzenlenebilirse, imgelerle gürleyen, seslerle çınlayan uzam da konuşur. (s. 77)

Dolayısıyla Artaud sahneyi tiyatronun canlı bir karakteri olarak düşünür. Sahne ses ve çığlığın yoğunluğunu hissettirdiği ölçüde baş karakter (protagonist) ya da karşıt karakterdir (antagonist). Sahne, uzamsal bir yerleşke olarak kendini hissettirmezse, önemsiz bir oyunun sıradan bir temsili mahiyetinde minör bir karakter olur. Bu yüzden Artaud "Vahşet tiyatrosu, tutkulu ve çırpınmalı bir yaşam kavramını tiyatroya geri getirmek için oluşturulmuştur; zaten, bu tiyatronun temel aldığ vahşeti, şiddetli sertlik ve sahne öğelerinin aşırı yoğunluğu anlamında anlamak gerekir” (s. 107) der.

\section{Edward Bond, Saved ve Vahşet Tiyatrosu}

Artaud, vahşet tiyatrosunun varoluş gerekçelerini sıralarken "istenilen tiyatro koşullarında sunulmuş bir cinayet imgesinin, aynı cinayetin gerçekleştirilmiş olanından son derece daha korkunç bir şey olduğuna inanç" (Artaud, 1993, s. 76) şartını önceler. Bu inancın gerçekleştirilmesi koşulu tecrübenin doğasına tam bir gerçeklik vurgusu yapar. Bu noktada Edward Bond'un önerdiği "Tecrübeden öğrenmek tam bir hatadır" (2000, s. 8) söylemi tartışmalıdır. Ancak Bond'un üzerinde odaklandığı konu daha çok insanın kötümser ve iyimser doğasıyla ilgilidir. Çünkü Bond kendisinin "Çoğu insan gibi tecrübelerden edindiği kadarıyla kötümser fakat doğası gereği iyimser biri” (s. 8) olduğunu iddia eder. Buradaki tecrübe kavramı insan yaşanmışlıklarının tümünü kapsar. Sözgelimi, işlenilen bir cinayet hem bir tecrübedir hem de bir hatadır. Dolayısıyla Artaud'nun tiyatro anlayışıyla ele alındığında, tiyatro, insanın en korkunç hatalarının en gerçekçi resmedildiği bir duyum alanıdır.

İlk gösterimi 1965 yılında Londra Royal Court Tiyatrosu'nda yapılan Saved oyunu, Artaud düşüncesindeki vahşet tiyatrosunun en belirgin örneklerinden birini sunar. Bond'un "gereksiz bir şekilde iyimser" (s. 7) olarak nitelendirdiği bu oyun, yazarın gençlik yıllarından bazı otobiyografik imgelemler taşır. Bond, kendi yaşantısını aktardığ 1 The Hidden Plot: Notes on Theatre and the State (Gizli Olaylar Zinciri: Tiyatro ve Devlet Üzerine Notlar) adlı eserinde, 18 Temmuz 1934'te doğduğunu, beş yaşındayken oturduğu bölgenin bombalandığını (İkinci Dünya Savaşı), on bir yaşına kadar bombalarla iç içe olduğunu aktarır (2000, s. 2). Ayrıca ordu görevindeyken düşmanlarını öldürmenin yöntemlerini öğrendiğini, içinde bulunduğu toplumun komşularını nasıl öldürebileceğini öğrettiğini, toplumsal eşitsizliği, yöneticilerin 'insan nedir?' sorusunu cevaplandıramadığını, kötülüğün iyiliği yok ettiğini ifade eder (s. 2). Bunlar şiddete maruz kalan bir bireyin öz anlatımlarıdır. Bu sözü geçen öncüllerin her biri ayrı ayrı Saved oyununda da belirir. Dolayısıyla oyun psikoanalitik ve şizoanalitik örneklemleri de barındırır.

Temelde 1960 Londra'sını canlandıran oyun dişavurumcu üslubu benimser. Oyun kişilerinden Len yazarın daha önce sözünü ettiği 'tecrübelerden edinilenler kadarıyla kötümser ancak doğası gereği iyimser' biridir. Oyunun ilk sahnesi Len ve Pam'in seks macerasıyla başlar. Pam'in babası Harry'nin onları izlemesi Len'i rahatsız etse de Pam bu davranışını oldukça bayağı karşılar. Olaylar, daha sonra yazar tarafindan bilinçli bir motif olarak seyirciye aksettirilen bir parkta geçer. Burada Fred karakteri oyuna dâhil olur ve Pam ile arasında bir yakınlaşma olur. İlerleyen bölümde oyuna Pete, Barry, Mike ve Colin dörtlüsünden oluşan bir gençlik çetesi dâhil olur ve yine diyaloglar bir parkta geçer. Oyunun sonraki sahnesinde annesi Pam olduğu anlaşılan isimsiz bir bebek belirir. Belli ki bebek Fred'tendir. Bebek sürekli ağlar; kimse tarafından benimsenmez ve hor görülür. Yine aynı parkta Len ve Fred balık avlarken, Pam bebek arabasıyla oraya gelir ve Fred'le tartıştıktan sonra bebeği orada bırakıp gider. Len de Pam'in peşinden gider. Bir süre sonra gençlik çetesi de Fred'in yanına gelir ve bebek ağlamaya başlayınca onu itip kakmaya çalışırlar. Önce Barry bebek arabasını sertçe Pete'ye iter, sonra bebeği susturmak için çimdiklerler. Fred de dâhil olmak üzere diğerleri de bebeği çimdiklemeye, üzerine tükürmeye, yüzüne kendi dışkısını sürtmeye başlarlar ve sonunda onu taşlayarak öldürürler. Onlar ayrıldıktan sonra Pam tekrar döner ve bebek arabasının içine bakmadan arabayı alıp gider. Sonrasında Fred suçlanır ve hapse 
atılır. Pam 1srarla Fred'in kendisine dönüşünü beklerken Fred Liz adındaki yeni kız arkadaşıla belirir. Oyun son sahnede Pam, Len, Harry ve Pam'in annesi Mary'nin birarada yaşantılarını gösteren bir tekinsiz sakinlikle son bulur.

Saved oyunu modern kapitalist toplumun acımasız doğasını açığa vurmaya çalışır. Çünkü oyun karakterleri tipik East End işçi sınıfı ruh halini, yaptıkları konuşmalar ise Cockney ağzını yansılar. Görünüşte oyunda basit yaşantıların sıradanlığına dair bir takım yaşanmışlıklar verilse de, şiddetin salt bir kent çetesine has olmadığı aynı zamanda sıradan insanların da yöneldiği bir araç olduğu gözlemlenir. Örneğin, Harry ve Mary'nin iletişimsizliğinin ardında, karı ve kocanın önceden yaşadığı şiddetli anlaşmazlıklar hissettirilir. Pam ilkin sıradan bir bireyi resmeden bir karakter olarak tanıtılır; ancak bebeğine yokmuş gibi davranması ile şiddeti hayatın sıradan bir parçası olarak kabul eden bir karaktere bürünmesi ile o sıradanlığı ortadan kalkar. İngiltere'deki sınıfsal sistemin eleştirisini yapan yazar, kapitalizmin sadece maddi koşulları değil, aynı zamanda insanların iç yaşamını ve birbirleriyle yaşama ölçütlerini etkileyen her şeyin köküne indiği inancını betimlemeye çalışır. Bu haliyle ekonominin de şiddete yön verdiği aktarılmaya çalışılır. Oyun yirminci yüzyılın ortalarındaki kentsel bozulmayı temsil eder ve insanların yaşadığı fiziksel ortamda pek fazla görünmeyen, daha şaşırtıcı şiddet örneklerini görünür kılmaya çalışır. Bu bağlamda kendisine cinsiyet verilmeyen bir bebek [oyunda bebek cansız veya insan dişı varlıklara ithafen kullanılan üçüncü tekil şahıs öznesi ile (it) hitap edilir] toplumun asla sınıflandırılmaması gereken her bir kesimini örnekler. Oyunda şiddet iki boyutuyla verilir. Sonuçları kadar sebepleri de vurgulanır. Oyunda şiddeti ortaya çıkaran unsurlar da açıkça ifade edilir. İşsiz bir genç kuşağı, uyuşturucu ve seks düşkünü bireyler, aileden yoksun kimseler, toplumsal bunalım ve yalnızlık şiddetin doğmasına sebep olan faktörlerdir. Aslında yazarın şiddeti kaleme alması da bilinçlidir. Yazar bununla ilgili olarak Lear adlı oyununun önsözünde şunu ifade eder:

Ben Jane Austen'ın görgü kuralları hakkında yazdıkları kadar doğal bir şekilde şiddet hakkında yazıyorum. Şiddet toplumumuzu şekillendirir ve bağımlı hale sokar ve şiddetten uzak durmazsak geleceğimiz yok olur. Şiddet hakkında yazanları engelleyenler kendimiz ve içinde bulunduğumuz an hakkında yazılmasına engel oluyorlardır. Şiddet hakkında yazmamak ahlaksızlık olur (Bond, 1978, s. 3).

Şiddeti sahneye koyan Bond, Artaud'nun vahşet tiyatrosunda benimsediği ses ve beden birliğini sahnede taşlanan bebek temsiliyle vermeye çalışır. Sahnede bebeğin çı̆̆lıkları, izleyicilerin 'en diri' katharsisi tatmalarını sağlar. Burada bebeğin vahşice öldürülmesi izleyiciler ya da okuyucular tarafından çok korkunç bir eylem olarak algılansa bile, oyundaki asıl dikkat eylemi gerçekleştirenlerin sakinliğine çekilmek istenir. Çünkü yazar insanı diğer varlıklardan ayıran 'düşünebilme' fonksiyonuna dikkat çekmek ister. Bu duruma benzer olarak Lear oyununun önsözünde hayvani şiddetle insani şiddet arasındaki ayrımdan söz eden Bond, kişilere "Türümüzün varlığı neden kendi yarattığı şiddetin tehdidi altında?” (s. 3) diye bir soru yöneltir. Bu soruya yine kendisi Saved oyununun önsözünde metaforik cevaplar verir: "Açıkçası Londra parkındaki bir bebeği taşlayarak öldürme tipik bir İngiliz hafife alışıdır" (2000, s. 7) diyerek sözüne başlar ve "Kentlerin 'stratejik' bombalanmasıyla karşılaştırıldığında, ihmal edilebilir bir zulümdür. Çoğu çocuğun kültürel ve duygusal yoksunluğuyla karşılaştırıldığında, sonuçlar önemsizdir” (s. 7) diye sözlerini sürdürür. Bu tablo Bond'un tam olarak kişilere aktarmaya çalıştığı şiddete duyarsızlaşan bir toplum gerçeğidir. İşte bu sebeple ses ve bedenin insanı tam bir bütün olarak sahnede gösterdiğini hissettirir. Bu böyle olmak durumundadır çünkü "Bu tiyatro, kişiliği ve duyguları iyice dilimlenmiş ruhbilimsel insana sırt çevirerek, yasalara boyun eğmiş, dinler ve dinsel buyruklarca özü değiştirilmiş insana değil, bir bütün olan insana seslenir" (Artaud, 1993, s. 108). Burada 'dinler ve dinsel buyruklarca özü değiştirilmiş insan' sözü Bond'un bu oyunuyla tam bir anlam kazanır. Çünkü Bond oyunun önsözünde şöyle der:

Çocuklara öğretilen hemen hemen tüm ahlak kuralları din temellidir. Bu, ilk başta onlarda şaşkınlık yaratır; çünkü diğer zamanlarda öğretilen bilim ve aklın aksine, dinin ebeveynlerinin kişisel yaşamları, ekonomik, endüstriyel ve siyasi hayatlarıyla hiçbir ilgisi yoktur. Onlara göre din sürdürmek istediği ahlakı reddeder. Sonuç şu ki bireyler ahlâki açıdan cahil ve anlayışsız yetişirler, çünkü ahlaki düşüncenin niteliği veya ahlaki değer hakkında öğretilmemişlerdir. Bu her zaman fark edilmez, çünkü hala ahlaki anlam taşıyan kelimeleri kullanırız, ancak bunlar hissedilmez. [...] Bu da şu anlama gelir, din inancını değil anlamayı/anlayışlı olmayı öğretmemiz gerektiği $(2000$, s. 8). 
Oyunun benimsediği öğreticilik ahlaki normların alt üst edilişinin yarattığı toplumsal krizlere dayanır. Nitekim oyunda Pam'in Len ile yaşadığı cinsel birlikteliğinde babasını görmezden gelmesi ahlaki bilincin olmayışı ile açıklanabilir, ancak burada Bond, Pam'in ebeveynleri olan Harry ve Mary arasındaki çatışmanın bir yansıması olan sessizliğin yarattığı psikolojik şiddete vurgu yapar. Pam'in bu sahnede babasına duyarsızlığı, psikoanalitik bir açıklamayı gerekli kılar. Çünkü anne-baba eksikliği ya da annebabanın çocukluk dönemlerindeki ilgisizliği sahnede başka bir travmanın varlığını ortaya koyar. Yalnızlığını bedensel bir eylemselliğe dönüştüren Pam, duygusal şiddetin tahribatını izleyiciye aksettirir. Duygusal şiddet Pam'in melankolik ruh haliyle yerini cinsel şiddete bırakır. Yazar şiddetin bu yönlerini sahneye koyarak izleyicide tam bir şok etkisi yaratmaya çalışır.

Duyarsızlığın bir diğer örneği de takım elbise giyerek sahnede beliren Pete'in sebep olduğu bir ölümdür. Kamyonetiyle ölümüne sebep olduğu kişinin cenazesine gitmek üzereyken arkadaşlarıyla bir araya gelen Pete, sorumsuzluğun yol açtığı lakaytlıkla fiziksel şiddetin bir temsilini sahnede oldukça rahat bir tavırla arkadaşlarına anlatır. Dil ve bedenin bu şekilde 'rahat' ifade edilişi ile Artaud'nun vahşet tiyatrosunda sözü edilen "İmgelerin ve hareketlerin birbirleriyle örtüşmesi sonucu, nesnelerin, sessizliklerin, haykırışların ve ritimlerin gizli uyuşumlarıyla, artık ana maddesi sözcükler değil de göstergeler olan gerçek fiziksel bir dilin yaratılmasına ulaşılacaktır” (Artaud, 1993, s. 109) söylemi dramatize edilir. Fiziksel dil sahnede fiziksel davranımlarla bütünleştirilirken, dilin toplumsal normların aksine hareket ettirilmesi de sağlanır. Bu da oyundaki neredeyse her diyalogdaki argo sözcüklerin, küfürlerin, aşağılamaların, pejoratif sözlerin varlığıyla ispatlanır. Kullanılan dil fiziksel varlığını ispat ettiği ölçüde 'sözlü şiddeti' de barındırır. Herbert Kretzmer'a göre “İlk sahneden son sahneye dek, Edward Bond'un oyunu cinsel ve fiziksel şiddetle alakalıdır. Neredeyse istisnasız olarak, tamamı küfürbaz, kirli fikirli, okuma yazma bilmeyen ve hemen hemen hiç tanınabilir insan seviyesinde görülemeyecek karakterlerle doludur" (Spencer, 1992, s. 13).

Artaud'nun "kesin ve kutsal kabul edilmiş metinlere dönmek yerine, her şeyden önce, tiyatronun metne bağımlılığını kırmak ve jestle düşünce arasında kalan bir tür benzersiz dil kavramını yeniden bulmak önemlidir" (1993, s. 79) sözleri Bond'un bu oyunundaki dördüncü sahnede tam olarak temsil edilir. Sahnede hiçbir olayın olmadığı durağan bir durum vardır. Basit eylemler, metinden ayrıştırılabildiği kadar önemli hale getirilir. Bu sahne okur için ne kadar sıradan olsa da izleyici için aynı değildir. Pam, Fred'le dışarı çıkmak için hazırlık yapmakta, Len, Harry ve Mary de akşam yemeği yemekteler. Bu sahneye vahşet tiyatrosunun yansıması işitsel ve görsel öğelerin gücüyle hissettirilir: son sese kadar açık bir televizyon ve sahne boyunca aralıksız ağlayan bir bebek. Bu sebeple sahnedeki asıl eylemsellik ve ciddiyet bebeğin ontolojik varlığını ispatlayan çığlıklarıdır. Bond izleyiciyi sürekli rahatsız etmeye çalışır. Metinde sıradan görünen nerdeyse her sahne, performansta büyük bir şok etkisi yaratır. Bond, bu şekliyle Artaud'nun benimsediği dikkat çekme öğesini vurgular. Çünkü tiyatronun görevi izleyiciyi uyarmak ve uyandırmaktır. İnsan doğasının bir yönü olan şiddet, en gerçekçi şekilde halkta özfarkındalık yaratmalıdır; bunun yolu da dikkati belirli durumlara yoğunlaştırma ile mümkündür. Bunu Artaud şöyle açıklar:

Demek ki, tiyatroyu, sözcüğün tam anlamıyla bir işleve dönüştürmek söz konusudur; yani, damarlardaki kanın dolaşımı ya da beyindeki duş imgelerinin görünüşte karmakarışık serpilmesi denli konumu belli ve açık seçik bir şeye; bu da, etkili bir zincirlenmeyle, dikkatin gerçek anlamda tutsak kılınmasıyla olanaklıdır. (s. 81)

Yazarın seçtiği başlık da metaforik olduğu ölçüde dikkat çekicidir. Toplumsal vahşetin var olduğu bir toplumda 'kurtulmayı' bekleyen yüzlerce dilsiz bebek olduğu gibi, yaşantılarıyla vahşeti kimlik edinen yüzlerce birey vardır. Bu yönüyle oyun aynı zamanda farklı şiddet unsurlarını diğer bireyler üzerinden de okura aktarmaya çalışır. Örneğin, Harry ve Mary arasındaki iletişimsizlik ve Pam'in vurdumduymaz tavırları ev içi ya da aile içi şiddetin temel belirtileridir. Oyundaki ebeveynler, sonradan ortaya çıkmış ev içi şiddetsizliğin var olmasında sakinlik ve sessizlikleriyle rol oynarlar. Ancak bu şiddetsizlik çok uzun süre devam etmiş bir şiddetin evirilmesi sonucu ortaya çıkmıştır. Nihayetinde, Pam'in davranımlarının psikoanalitik çözümlemesi yapıldığında, ebeveynlerine karşı ilgisiz veyahut içe kapanık tavırlara bürünmesinin ardında maruz kaldığı aile içi şiddet söz konusudur. Burada ilgisizliğe maruz kalan Pam, aynı ilgisizliği bebeğine gösterir.

Harry ve Mary arasında süregelen iletişimsizlik, Pam'in ilişkilerine de yansır. Fred ile duygusal bir yakınlığı bulunan Pam, çoğunlukla Fred ile görüşmelerinde sözlü ya da dilsel şiddet yaşar. Aslında dilsel 
şiddet gençlik çetesinin bütününde belirir. Karakterlerin bir araya gelişlerinde sarf ettikleri konuşmalar, kullanılan dilin sert bir üslupla karşıya bir tehdit ya da baskı aracı olarak uygulandığını gösterir. Fred ve Pam arasındaki diyaloglarda, argonun yanında, dil zorbalığı yapılarak şiddet hedeflenmiş olur. Bu sayede, dil tam bir şiddet aracı olarak işlev görür. Dilsel şiddet, aşırıya gittiği ölçüde karakterlerin fiziksel şiddete meyletmesini tetikler. Oyunun altıncı sahnesinde, karakterlerin fiziksel şiddete ne kadar yönelimli olduğu öncelikle kullandıkları dilsel şiddet ile belirir. Daha sonra her bir karakter bir diğerini bu yönde teşvik eder. Ve nihayetinde fiziksel şiddet kaçınılmaz olur.

Bond, bu sebeplerle, okurun oyunun başlığını karakterler ve toplumla ilişkilendirmesini sağlar. Kurtulmaya çalışan bir bebek olduğu kadar, kurtulmaya çalışan bir toplum da mecazi olarak anlamlandırılmaya çalışılır. Çünkü yazarın uyandırmaya çalıştığı farkındalık muhtemelen gençlik çetesine katılacak, muhtemelen şiddet yanlısı olacak, muhtemelen topluma zarar verecek başka bir bireydir. $\mathrm{Bu}$ sebeple yazar, önsözde, "İnsanların davranışlarını iyileștirmek için öncelikle ahlaki anlayışlarını arttırmalıyız ve bu, çocuklara ahlakı ikna edici biçimde öğretmek demektir” (2000, s. 7) der. Dini ayinlerden çok, anlamlı bir birey yetiştirilmeye özen gösterilmesi gerektiği düşüncesini de oyunda, Christ (İsa) yerine Chriss (İngilizce’deki crisis sözcüğüne göndermede bulunarak) ismini kullanarak hiciv yapar.

\section{Sonuç}

Bu oyunu sahneye koyan yapımcılardan Sean Holmes bir röportajda, "Açıkçası bana öyle geliyor ki aslında Saved insan olmakla alakalıdır" (Billingham, 2014, s. 82) der. Bond şiddetin insana ne yaptı̆̆ıyla ilgilenmez; şiddete nasıl çözüm üretilmeli fikri üzerinde durur. Oyunda şiddet insan yaşamının doğal bir parçası olduğu düşüncesinden öte, insanın içinde bulunduğu toplumun 'insanlıktan çıkma' yönlerinin doğal sonucu olup, insanın sanayileşmiş dünyanın çalışma biçimine uyması uğruna fiziksel ve psikolojik açıdan boyun eğmesi, kişinin kendi hayatı üzerindeki kontrol eksikliği olarak analiz edilir. Yazar Ataud'nun vahşet tiyatrosunu sahneye koyarken, "Tiyatro bütün olanaklarıla, yalnızca nesnel ve diş betimsel dünyanın görünümlerini değil, aynı zamanda içimizdeki dünyanın görünümlerini, yani metafiziksel olarak ele alınan insanın görünümlerini sorunsal kılmayı amaç edinmelidir" (Artaud, 1993, s. 81) fikrini benimser ve uygular. Dolayısıyla oyunun vurguladığ 1 şiddet/vahşet yalnızca dilsiz bir bebeğin içsel tahribatını bizlere aktarmaz; oyun aynı manada, kişilik bozukluğu izlenimi veren Len'in, ilgisizlikten ve yalnızlıktan dem vuran Pam'in, sessizliği bir iç travma olarak örnekleyen Harry ve Mary'nin, suçluluk bilincini oturtamayan Fred'in, öldürmeyi bir eğlence olarak sayan Pete'in tragedyasını her biri toplumun herhangi bir ferdi olarak sahneler.

Artaud'nun "Etkinlik gösteren her şey vahşettir" ilke sözü Bond'un bu oyununun her sahnesinde kimlik kazanır. Eylemler, şiddet temsil edildiği ölçüde, vardır. Sahnelerdeki şiddet olgusu sessel ve bedensel örgütlemelerle kişiler tarafından izleyiciye aşılanır. Bond, şiddetin toplumsal bir felaket olduğunu bu imgelemleri güçlü kılarak aktarır. Sahnede ağladığı için taşlanarak öldürülen bir bebek, toplumda var olan bir sorunun ortadan kaldırılmasında kişilerin başvurduğu şiddetin bir temsilidir. Çünkü Bond'a göre "Aslında en sosyal ve kişisel problemler yalnızlaştırma veya öldürme yoluyla çözülür" (Hirst, 1985, s. 91). Bu sebeple, oyun kaosa sürüklenme yolunda olan toplumlardaki bireylerin kurtulmalarına yön verecek muhtemel çözümleri okurda veyahut izleyicide uyandırmayı esas edinir. Bu sebeple, Bond'un bu oyunu toplumsal vahşetin bir senaryosu olduğu kadar, bireylerde farkındalık yaratmanın da bir senaryosudur.

\section{Kaynakça}

Artaud, A. (1993). Tiyatro ve İkizi (Çev. Bahadır Gülmez). İstanbul: Yapı Kredi Yayınları.

Bermel, A. (2001). Artaud's theatre of cruelty. London: Methuen Drama.

Billingham, P. (2014). Edward Bond: A critical study. New York: Palgrave Macmillan.

Bond, E. (1978). Bond's plays 2. London: Methuen Drama.

Bond, E. (2000). Saved. London: Methuen Drama.

Bond, E. (2000). The hidden plot: Notes on theatre and the state. London: Methuen Drama. 
Davis, D. B. (1966). Violence in American literature. The Annals of the American Academy of Political and Social Science, 364: 28-36. Erişim adresi: https://www.jstor.org/stable/1034751?seq=1\#page_scan_tab_contents

Derrida, J., ve Thevenin P. (1998). The secret art of Antonin Artaud. Cambridge and London: MIT Press.

Docker, J. (2008). The origins of violence: Religion, history and genocide. Sydney: UNSW Press.

Dursun, Y. (2011). Şiddetin izini sürmek: Şiddet nedir? Felsefe ve Sosyal Bilimler Dergisi, 12: 1-18. Erişim adresi: http://www.flsfdergisi.com/sayi12/1-18.pdf

Galtung, J. (1969). Violence, peace and peace research. Journal of Peace Research, 6, (3), 167-191. Erişim adresi: https://www.jstor.org/stable/pdf/422690.pdf?refreqid=excelsior\%3A0727ab20c04611 cc1f9893c8f31bef49

Govier, T. (2008). Violence, nonviolence and definitions: A dilemma for peace studies. The Canadian Journal of Peace and Conflict Studies, 40(2), 61-83. Erişim adresi: http://www.jstor.org/stable/23607798

Gülmez, B. (1993). Çevirenin Notu. Tiyatro ve İkizi. İstanbul: Yapı Kredi Yayınları.

Hirst, D. L. (1985). Edward Bond. London: Macmillan Publishers.

Krug, E. G. (2002). World report on violence and health vol. 1. Geneva: World Health Organization.

Lawson, K., ve Shakinovsky, L. (2002). The marked body: Domestic violence in mid-nineteenth century literature. New York: Suny Press.

Morris, S. C. (2007). The causes of violence and the effects of violence on community and individual health. Global Health Education Consortium.

Spencer, J. S. (1992). Dramatic strategies in the plays of Edward Bond. New York: Cambridge University Press.

Şiddet. (t.y.). Türk Dil Kurumu güncel Türkçe sözlük içinde. Erişim adresi: http://www.tdk.gov.tr/index.php?option=com_gts\&arama=gts\&guid=TDK.GTS.597b23a2dab913.04449483

Ünlü, A. (2007). Şiddete gülmek: Geleneksel Türk tiyatrosunda şiddet ve mizah. Ankara Üniversitesi Tiyatro Araştırmaları Dergisi, 24, 27-41. Erişim adresi: http://dergiler.ankara.edu.tr/dergiler/13/905/11572.pdf

VandenBos, G. R. (2015). APA dictionary of psychology. Washington: American Psychological Association.

Violence. (t.y.). Online Oxford dictionary güncel sözlük içinde. Erişim adresi: https://en.oxforddictionaries.com/definition/violence

Yılmaz, A. (2005). Türk romanında aile içi şiddet teması. Türkbilig, 10, 131-149. Erişim adresi: http://dergipark.gov.tr/download/article-file/143058 